\title{
Relative Importance Index (RII) in Ranking the Factors of Employer Satisfaction Towards Industrial Training Students
}

\author{
Duratul Ain Tholibon $1^{*}$ h https://orcid.org/0000-0002-2729-2694, Masyitah Md Nujid 2 https://orcid.org/0000-0002-4332-

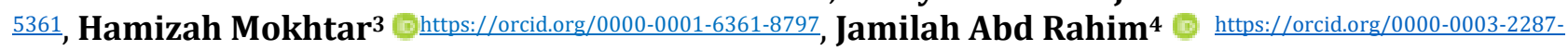 \\ 2224, Nurul Faiizin Abdul Aziz ${ }^{5}$, Amirah Amalina Ahmad Tarmizi6 ${ }^{\circ}$ https://orcid.org/0000-0001-7745-9432 \\ 1,3,4,5School of Civil Engineering, College of Engineering, Universiti Teknologi MARA, Cawangan Jengka, \\ 26400 Bandar Tun Razak, Pahang, Malaysia \\ ${ }^{2}$ School of Civil Engineering, College of Engineering, Universiti Teknologi MARA, Cawangan Pulau \\ Pinang, Permatang Pauh Campus, 13500 Pulau Pinang, Malaysia \\ ${ }^{6}$ Department of Chemistry, Faculty of Applied Science, Universiti Teknologi Mara Shah Alam, Selangor, \\ Malaysia \\ *e-mail: ${ }^{1 *}$ duratulaintholibon@gmail.com
}

\begin{tabular}{l}
\multicolumn{1}{c}{ Article Information } \\
\hline Received: April 26, 2021 \\
Revised: June 30, 2021 \\
Accepted: October 10, 2021 \\
Online: November 15, 2021
\end{tabular}

$\frac{\text { Keywords }}{\text { Computer simulation, Secondary }}$
physics

\begin{tabular}{l} 
ABSTRACT \\
\hline This study aims to examine the level of employer satisfaction \\
towards industrial training students of the UiTM Pahang Civil \\
Engineering Diploma Program and identify employer \\
satisfaction factors for industrial training students from \\
aspects of knowledge, personality, generic skills, and soft \\
skills. This study is focused on semester four students \\
undergoing industrial training. This study was conducted on \\
158 respondents from various organizations. Using the \\
important relative index (RII), the level of important factors \\
was ranked through the value of the index. Findings show the \\
highest employer satisfaction is towards the student \\
mastering their knowledge, adhering to the working hours, \\
improving their skills and knowledge, and communicating \\
well with co-workers. Besides, it also shows a good correlation \\
between knowledge and personality among industrial \\
training students. This study found that industrial training \\
students of the Civil Engineering Diploma Program had a \\
good level of control over all four domains. Overall findings \\
showed that employers are satisfied with the industrial \\
training students of the UiTM Pahang Civil Engineering \\
Diploma Program. This study is important to measure the \\
effectiveness of the industrial training syllabus in terms of \\
achieving the program outcomes addressed in the syllabus.
\end{tabular}

\section{INTRODUCTION}

Industrial training is a program that exposes students to 'Professional Engineering Practice' and the entire construction industry. Industrial Training is mandatory for the Faculty of Civil Engineering students who have undergone diploma-level study at Universiti Teknologi MARA (UiTM) Malaysia. The industrial training missions are to provide expertise, training, and exposure to the real world of construction and engineering in producing competitive engineers globally. In addition, it provides engineers who can develop the nation towards becoming a developed country status in equivalent to 
other developed countries. Industrial training placement is all over Malaysia, covering the Northern, Southern, Eastern, and Western states of Malaysia. Students can also self-choose the organizations that provide this training comprising government bodies such as local authorities and private companies such as contractors, consultants, and real estate developers.

Students' interpretations of their experiences and lessons have been the subject of previous studies (Mihail, 2006; Warinda, 2020). According to Devi et al. (2019), the restricted length of time, low student salary or wages payment, and long working hours are shortcomings of internship programs. The outcomes of internship programs vary depending on the course. On the other hand, unstructured internship programs push students to do the same uninteresting and tedious job every day when they expect challenging jobs with opportunities to learn and contribute to the organization (Rothman, 2007; Chiu et al., 2016). While an intern might not delegate to advanced projects, repetitive assignments can negatively impact an intern's experience (Chiu et al., 2016; Matturro et al., 2019).

As a result, institutions must look at how their students are acknowledged in the job market. According to Fairuzza et al. (2011), many Malaysian university graduates still lack relevant soft skills competency, resulting in unemployment in a highly competitive job market. According to the National Economic Action Council (2003), there is a discrepancy of competency between the industry necessities and the graduates generated by the universities. Similarly, the results of Universiti Tun Hussein Onn Malaysia revealed differences between the value of soft skills in the workplace and graduates' soft skills competency output as viewed by Human Resource Practitioners (Azmi et al., 2018). Furthermore, emphasizing the value of improving soft skills, Malaysia's Education Ministry has decided to introduce two-year learning and two-year practical training for university courses under the blueprint. According to Ilhaamie et al. (2018), having good English proficiency and communication skills would make Malaysian graduates more marketable. Meanwhile, it aligns with the Malaysia Education Blueprint 2015-2025 (Higher Education) goals of cultivating talent and creativity to create holistic and entrepreneurial individuals.

In line with the importance of understanding undergraduate efficiency, this paper will focus on examining the performance of Universiti Teknologi MARA (UiTM) diploma students in industrial training programs. The main focus of the study is to measure and rank the satisfaction level of employers towards the students' level of basic knowledge, generic skills, soft skills, and personality, which employers commonly seek. The findings of the investigation will be helpful for the university to identify the skills that the students acquire throughout the learning process that will meet and fulfill the employer's requirement.

\section{Literature review}

To improve the quality of industry training, this study focuses on employers' perceptions of the skills employed by industry trainers. Shazaitul Azreen Binti Rodzalan (2016) suggested that as an employer, the responsibility is to select and employ potential workers and place them in work related to their vocational training. The employers' perceptions can usually be seen through feedback from industrial training reports and logbooks of students who have undergone industrial training in their workplace. Working skills, or "Employability" skills, are important because individuals with good technical skills but no employability skills are considered low quality. Some factors or skills needed in the occupation world are closely related to satisfaction and employer perception. However, this study focuses only on four major skills for industrial training students in the Institute Of Higher Education (IPT): knowledge acquisition, personality, generic skills, and soft skills found to influence employer satisfaction.

\section{Knowledge Acquisition}

Based on the Zhukova (2020) findings, labor demand (employment vacancy) is in line with labor supply, but employer priorities are knowledgeable and skilled workers who are not directly related to the field of work. Therefore, educators should also be involved in helping students to equip and enhance the knowledge and skills required in the employment sector (Ariff et al., 2017). Various ways can be used to help university students improve their job skills. Among the suggested results of the study report by Chiu et al. (2016) and Mai (2012) are industrial training requirements, training skills packages, and integration of skills components in the curriculum. 
Students should demonstrate their knowledge skills in order to conquer the demands of today's workplace better. Students' understanding of having information about the attached organization, the given tasks or projects, the application of subject learning, and some current issues concerning them is assessed by basic knowledge. Awareness is assessed in terms of area of research, accountability, relevant business, and current issues. Their "real-life" work experience will finally provide them with an opportunity to improve their personal and employability skills further. Technical and generic skills, both of which are important in the workplace that develop employability skills. Technical skills are skills related to particular subjects that are generally learned in a structured classroom environment. For example, mathematical, engineering, research, computer-related duties, and other particular tasks require knowledge and skill. (Gibert et al., 2017)

Technical skills are considered specialized knowledge and analytical ability in using tools and techniques in certain disciplines such as civil engineering, electrical engineering, electronics, or information systems (Hashamuddin Yaakob et al., 2018). Skills can be defined as the ability to successfully achieve something which requires special knowledge or ability or competence. Besides, the skills are also meant as an art, the ability or technique acquired through training or experience, which involves limbs. Finally, technical skills refer to understanding and efficiency in particular activities, particularly methods, processes, procedures, and techniques.

Scholars teach various definitions of knowledge in the field of knowledge sharing. Knowledge is a combination of experience, value, learning, information skills, and personal understanding. Knowledge is also defined as the experience and understanding of individuals translated into meaningful forms and used to carry out tasks. Newly created knowledge can be spoken, formulated, written, drawn, and collected by individuals (Hashamuddin Yaakob et al., 2018). This knowledge can be stored in various formats such as documents, pictures, and videos. Knowledge is divided into two that is implicit and explicit knowledge. Implicit knowledge is personal knowledge based on individual experience and involves instinct, personal values, and beliefs (Hashamuddin Yaakob et al., 2018). For example, in Institutions of Higher Learning, the implied knowledge created by academics and embedded in their minds is an intellectual warehouse.

In recruiting new employees, the job market always emphasizes working experience in addition to certificate qualifications. Hence, the need for industrial training or working experience becomes the basis of an institution of higher learning (Pereira \& Raposo, 2019). In Malaysia, higher learning institutions now allow students to translate the knowledge acquired into practice through industrial training. The training period that lasts about six months aims to develop knowledge in line with the industry's skills, which seems to be an important part of providing a quality and professional workforce in the future.

Knowledge is an important aspect of improving development and productivity. There are two important criteria in ensuring that economic development in Australia is constantly increasing by increasing the knowledge and level of skills in current or future employment. First, knowledge-based economies will add growth sources through activities that increase added value and thus contribute to the Overall Productivity Factor. To achieve this stage, workers need to be equipped with the skills and knowledge to enhance creativity and innovation to bring about economic growth in the era of globalization and liberalization (Carneiro da Cunha Custódio \& Gomes da Silva, 2020). The ability to generate knowledge, share existing knowledge, and apply knowledge related to the organization to a new atmosphere is critical.

\section{Personality}

Mass media reports have voiced some of the weaknesses of local graduates, including their skills and personality traits, affecting their chances of getting a job. Ilhaamie et al. (2018) agree that the successful generation of youths is the one who has a comprehensive education of Islam, whose intelligence is supplied with all knowledge, the body trained with all the strength of the special and general worship and its character is cultivated with noble values. Good manners are the foundation of the brilliant youth generation and produce the people who can contribute to the nation's vision ( $\underline{\mathrm{Ng} \&}$ Ahmad, 2018). 


\section{Generic Skills}

Generic skills are required by students and academics to be more successful and excel as practitioners in academic, occupational, and life. Generic skills are integrated with teaching and learning in the context of study subjects and are transferable skills (Shazaitul Azreen Binti Rodzalan, 2016; Chiu et al., 2016). In Malaysia, the students' generic skills assessment at Higher Education Institutions (IPTs) has been focused on achieving the Malaysian Qualification Framework (MQF) (Shakir, 2009). Generic skills are needed by students and academics to become more successful and excel in academia, work, and life. Generic skills can be applied across a range of subject areas, employment, and life contexts and are related to soft skills, which are still lacking in our graduates and need significant transformation to meet employers' standards (Fairuzza et al., 2011). Furthermore, according to their research, all soft skills found in the Intel Elite Programmed soft skills training, such as communication, innovative and critical thinking, teamwork, programmed and project management, and decision-making and problemsolving skills, are vital in the workplace.

Aspects of human skills need to be applied to complement technical skills. Soft Skills are generic skills. Soft skills lead to mastery in a skill focused on developing personal skills, personality, and humanity. Soft skills that can display high personality values include leadership, teamwork ability, critical thinking, problem-solving skills, ethics, and professional morals. The polytechnic graduates have gone through a special phase in equipping themselves with the technical skills of knowledge in specialized disciplines throughout the study. In line with the industry's needs, various efforts are being made to strengthen the study curriculum to improve marketability, emphasizing generic skills.

\section{Soft Skills}

The study conducted by Chiu et al. (2016) throughout the country shows that the seven soft skills offered by the Malaysian Ministry of Higher Education align with what the prospective interviewer has suggested. Communication skills, critical skills and problem-solving, teamwork skills, continuous learning and information management, entrepreneurial skills, ethics and professional morals, and leadership skills are included under the umbrella of the concept of emotional intelligence.

Soft skills are a combination of knowledge, skills, and personal characteristics needed in the app by employees in their daily lives (Gibert et al., 2017; Pereira \& Raposo, 2019). Aspects of soft skills need to be applied to complement technical skills. Soft skills lead to mastery in a skill focused on developing personal skills, personality, and humanity. Most soft skills can display high personality values such as leadership, teamwork ability, critical thinking, problem-solving skills, ethics, and professional morals (Hashamuddin Yaakob et al., 2018). Soft skills focus on students' self-development who can encourage and embrace interest, motivation, and spirit in the organization. Soft skills should be applied to complement technical skills (Shazaitul Azreen Binti Rodzalan, 2016). An organizational environment requires a soft skills program to give students confidence and motivation.

\section{METHODS}

This study is quantitative and qualitative (mixed method) with a survey design. In general, this study is organized by the study's conceptual framework and variables, i.e., dependent and independent variables. The classification of this variable depends on the level and question of the study. In two situations, the possibility of a variable is classified as a free variable for problem-solving. Besides, data from qualitative sources involving studies of library resources, including research-related documents and individual interviews, are also examined and identified to establish triangulation data. This design aims to obtain general information through a comprehensive quote from a population. The purpose is to collect data about the variables associated with a phenomenon without questioning why these variables exist. This instrument is effective in measuring large populations and large samples. However, on other issues, it acts as a dependent variable based on the level and question of the study.

Questionnaires were used in this study to identify employer satisfaction factors for students undergoing industrial training in their institutions and organizations in terms of knowledge acquisition, personality, generic skills, and soft skills of industrial training students. In addition, it acts as an instrument for data acquisition work through samples that have been randomly selected to represent 
the selected population from employers' circles who have previously employed the industrial training students of the diploma program of civil engineering to undergo a practical session at their place.

Section A of the questionnaires covered the respondents' backgrounds, while Section B asked respondents to provide input on their employers' satisfaction concerning industrial training students regarding knowledge acquisition, personality, generic skills, and soft skills. This section used the same measurement based on the level of agreement using a 5-point Likert scale, and the assessment was made based on the degree of agreement: 1 - Strongly Disagree; 2 - Disagree; 3 - Somewhat Agree; 4 - Agree; 5 - Strongly Agree; 6 - Strongly Agree. In addition, a reliability study using Cronbach's alpha was calculated for the variables measuring the same dimension to demonstrate reliability. The higher the accuracy and stability of an instrument, the more accurate it is, with a value of 0.70 that is considered appropriate.

Finally, calculating the Relative Importance Index (RII) is important in this study since the value of the index specifies the ranked degree of importance. It is especially useful for questionnaires that use a Likert scale. The RII formula was introduced into Microsoft Excel 2016 to determine the index for sets of objects, as seen in Eq. 1.

$$
\text { Relative Importance Index }=\frac{\sum w}{A N}=\frac{5 n_{5}+4 n_{4}+3 n_{3}+2 n_{2}+1 n_{1}}{5 N} \quad \text { Equation } 1
$$

Where $\mathrm{w}$ is the respondent's weighting of each factor, which can range from 1 to 5 , for instance, $\mathrm{n} 1$ represents the number of respondents for Not Important, $\mathrm{n} 2$ represents the number of respondents for Less Important, $\mathrm{n} 3$ represents the number of respondents for Moderately Important, $\mathrm{n} 4$ represents the number of respondents for Important, and $n 5$ represents the number of respondents for Very Important. Thus, the highest weight (in this case, 5 ) is A, and the total number of people labeled as $\mathrm{N}$. The Relative Importance Index ranges from 0 to 1.

An inter-correlation analysis was used in this study to explain the intensity and direction of each variable's linear relationship. Thus, the study defines the relationship between variables and also the degree of that relationship. Since the data is standard, a parametric test was used to measure and interpret a Pearson product-moment correlation coefficient ( $r$ ) for interval-level variables used in the questionnaire design. The value, which varies from -1.0 to +1.0 , shows both the direction (+ve and -ve) and the intensity of the relationships. In a positive correlation, all variables are trending in the same direction, whether increasing or decreasing together or vice versa. As seen in Table 1, (Goller et al., 2020) propose the following guidelines.

Table 1. Pearson coefficients

\begin{tabular}{lll}
\hline Pearson Correlation coefficients (r) & Value & Strength of Correlation \\
\hline Between .10 and .29 & Small & Poor relationship \\
Between .30 and .49 & Medium & Medium relationship \\
Between .50 and 1.0 & Large & Strong relationship \\
\hline
\end{tabular}

\section{RESULTS}

Four questions were asked in this section to find out the respondents' background. The questions included questions about gender, age, working duration, and education level obtained by respondents.

Table 2. Respondents background demographics distribution

\begin{tabular}{llll}
\hline No. & Respondents Background & Category & $\%$ \\
\hline 1 & Gender & Male & 32 \\
& & Female & 68 \\
2 & Age & $20-30$ years & 35 \\
\hline
\end{tabular}




\begin{tabular}{llll}
\hline No. & Respondents Background & Category & $\%$ \\
\hline \multirow{3}{*}{3} & $31-40$ years & 39 \\
& & $41-50$ years & 17 \\
& $51-60$ years & 10 \\
& Working Duration & $1-10$ years & 56 \\
& $11-20$ years & 30 \\
& & $21-30$ years & 8 \\
& \multirow{3}{*}{ Education Level } & $31-40$ years & 6 \\
& & Contractor & 36 \\
& & Consultant & 21 \\
& & Government Agency & 30 \\
& & Local Authority & 5 \\
& & Developer & 8 \\
\hline
\end{tabular}

Table 2 above shows that nearly $70 \%$ of the employers are male, which shows that men more pioneered civil engineering. It makes the total number of respondents who answered this questionnaire was 158. Almost $40 \%$ of the respondents were aged 31-40 years old, and almost half of the $56 \%$ had over 1 to 10 years of working experience. Also, the most engaged organizational sector is the contractor's 36.3\%, followed by $30 \%$ government agencies.

\section{Descriptive Analysis}

This section presents the employers' satisfaction concerning industrial training students regarding knowledge acquisition, personality, generic skills, and soft skills. The survey uses a scale of 1 to 5 that interprets a minimum value of 1 to a maximum of 5 .

\section{Empowering of Knowledge among Industrial Training Students}

The analysis in this section encompasses the level of a student's knowledge and application during industrial training. Table 3 shows the ranking of students' knowledge and application during industrial training under five (5) levels of students' knowledge and application during the industrial training domain. First, it shows that the majority of the students can master knowledge in the field of study and ranked this as the most important variable attributed to the student's knowledge and application during industrial training. Next is their ability to apply the relevant sciences, followed by answering questions about job assignments. However, they ranked their ability to provide suggestions and ideas on the field of work as the least important. Third, it shows that the knowledge of industrial training students meets the level of employer satisfaction. Fourth, it proves that the students can apply the knowledge that they acquire from the previous semester. Finally, it is proven that the students have undergone industrial training at the right company that involves directly in civil engineering works.

Table 3. Ranking of student's knowledge and application during industrial training using Relative Important Index (RII)

\begin{tabular}{|c|c|c|c|c|c|c|c|c|}
\hline \multirow{2}{*}{$\begin{array}{l}\text { Level of a student's } \\
\text { knowledge and } \\
\text { application during } \\
\text { industrial training. }\end{array}$} & \multicolumn{5}{|c|}{$\begin{array}{l}\text { Level of Agreement using the } \\
\text { Likert Scale }\end{array}$} & \multirow[t]{2}{*}{ Mean } & \multirow[t]{2}{*}{ RII } & \multirow[t]{2}{*}{ Rank } \\
\hline & 1 & 2 & 3 & 4 & 5 & & & \\
\hline $\begin{array}{l}\text { 1) Students can master } \\
\text { knowledge in the field of } \\
\text { study well. }\end{array}$ & 1 & 0 & 22 & 92 & 41 & 4.1 & 0.810 & 1 \\
\hline $\begin{array}{l}\text { 2) Students can provide } \\
\text { suggestions and } \\
\text { suggestions on the field of } \\
\text { work. }\end{array}$ & 1 & 3 & 46 & 73 & 33 & 3.9 & 0.762 & 5 \\
\hline
\end{tabular}




\begin{tabular}{|c|c|c|c|c|c|c|c|c|}
\hline \multirow{2}{*}{$\begin{array}{l}\text { Level of a student's } \\
\text { knowledge and } \\
\text { application during } \\
\text { industrial training. }\end{array}$} & \multicolumn{5}{|c|}{$\begin{array}{l}\text { Level of Agreement using the } \\
\text { Likert Scale }\end{array}$} & \multirow[t]{2}{*}{ Mean } & \multirow[t]{2}{*}{ RII } & \multirow[t]{2}{*}{ Rank } \\
\hline & 1 & 2 & 3 & 4 & 5 & & & \\
\hline $\begin{array}{l}\text { 3) Students can answer } \\
\text { questions raised in terms } \\
\text { of job assignments. }\end{array}$ & 1 & 2 & 34 & 81 & 38 & 4.0 & 0.786 & 3 \\
\hline $\begin{array}{l}\text { 4) Students can apply the } \\
\text { relevant sciences. }\end{array}$ & 1 & 2 & 25 & 89 & 39 & 4.0 & 0.799 & 2 \\
\hline $\begin{array}{l}\text { 5) Students can argue } \\
\text { according to relevant } \\
\text { disciplines. }\end{array}$ & 1 & 3 & 32 & 89 & 31 & 3.9 & 0.777 & 4 \\
\hline
\end{tabular}

\section{The personality of Industrial Training Students}

A good personality is the foundation of a brilliant youth generation and can produce a person contributing to the nation's vision (Harun Din, 1991). This section will analyze the level of the personality of industrial training students when in the environment of work. The analyses include time, relationship, appearance, ability, and obedience in carrying out the assignment. Table 4 shows the Personality of Industrial Training Students' ranking under seven (7) levels of student's personality domain. First, it shows that majority of the students can follow their working hours throughout the training period. Next is their appearance is good and interesting, followed by their ability to mingle with colleagues. Finally, however, they ranked their ability to organize the work priorities as the least important. Finally, it indicates that the engagement of curricular activities throughout their previous semester contributes to their good personality.

Table 4. Ranking of the personality of industrial training students using Relative Important Index (RII)

\begin{tabular}{|c|c|c|c|c|c|c|c|c|}
\hline \multirow{2}{*}{$\begin{array}{l}\text { Level of Personality of } \\
\text { Industrial } \\
\text { Students }\end{array}$} & \multicolumn{5}{|c|}{$\begin{array}{l}\text { Level of Agreement using the } \\
\text { Likert Scale }\end{array}$} & \multirow[t]{2}{*}{ Mean } & \multirow[t]{2}{*}{ RII } & \multirow[t]{2}{*}{ Rank } \\
\hline & 1 & 2 & 3 & 4 & 5 & & & \\
\hline $\begin{array}{l}\text { 1) Students can follow } \\
\text { their working hours } \\
\text { throughout the training } \\
\text { period. }\end{array}$ & 1 & 2 & 9 & 47 & 97 & 4.5 & 0.892 & 1 \\
\hline $\begin{array}{l}\text { 2) Students fully utilize } \\
\text { the time of work by } \\
\text { completing the } \\
\text { assignment given. }\end{array}$ & 1 & 0 & 10 & 74 & 71 & 4.4 & 0.863 & 5 \\
\hline $\begin{array}{l}\text { 3) Students follow the } \\
\text { dateline in completing } \\
\text { assignments. }\end{array}$ & 1 & 0 & 12 & 73 & 70 & 4.3 & 0.859 & 6 \\
\hline $\begin{array}{l}\text { 4) Students are able to } \\
\text { mingle with colleagues. }\end{array}$ & 1 & 1 & 10 & 59 & 84 & 4.4 & 0.872 & 3 \\
\hline $\begin{array}{l}\text { 5) Students can organize } \\
\text { their work priorities. }\end{array}$ & 1 & 0 & 17 & 85 & 52 & 4.2 & 0.825 & 7 \\
\hline $\begin{array}{l}\text { 6) Student's appearance is } \\
\text { good and interesting. }\end{array}$ & 1 & 0 & 5 & 65 & 85 & 4.5 & 0.887 & 2 \\
\hline $\begin{array}{l}\text { 7) Students can hold } \\
\text { institutional trust very } \\
\text { well. }\end{array}$ & 1 & 0 & 9 & 73 & 73 & 4.4 & 0.867 & 4 \\
\hline
\end{tabular}




\section{Generic Skills for Industrial Training Students}

Students and academics require generic skills to become more successful and excellent in academic, occupational, and life. This section analysis related to the level of generic skills of industrial training students based on the answers given by respondents in the questionnaire. Assessment in this section is about the ability of students to solve tasks or problems, students' skills either in technology or in management systems. Table 5 shows the ranking of Generic Skills for Industrial Training Students under eight (8) levels of students' generic skills domain. It shows that majority of the students can try to improve their skills and knowledge. Next is their practice of self-safety awareness aspects in carrying out their duties, followed by their ability to master their technological skills well. Finally, however, they ranked their ability to solve problems related to assignments as the least important. It indicates that students are willing to take the opportunity of industrial training to improve their knowledge and skills and apply lifelong learning in their learning style.

Table 5. Ranking of generic skills for industrial training students using Relative Important Index (RII)

\begin{tabular}{|c|c|c|c|c|c|c|c|c|}
\hline \multirow{2}{*}{$\begin{array}{l}\text { Level of Generic Skills } \\
\text { for Industrial Training } \\
\text { Students. }\end{array}$} & \multicolumn{5}{|c|}{$\begin{array}{l}\text { Level of Agreement using the } \\
\text { Likert Scale }\end{array}$} & \multirow[t]{2}{*}{ Mean } & \multirow[t]{2}{*}{ RII } & \multirow[t]{2}{*}{ Rank } \\
\hline & 1 & 2 & 3 & 4 & 5 & & & \\
\hline $\begin{array}{l}\text { 1) Students can do the } \\
\text { task given with minimum } \\
\text { supervision. }\end{array}$ & 2 & 1 & 26 & 84 & 42 & 4.1 & 0.795 & 6 \\
\hline $\begin{array}{l}\text { 2) The work reached the } \\
\text { standard level that the } \\
\text { employer had set. }\end{array}$ & 1 & 0 & 22 & 97 & 36 & 4.1 & 0.804 & 5 \\
\hline $\begin{array}{l}\text { 3) Students can solve } \\
\text { problems related to } \\
\text { assignments. }\end{array}$ & 1 & 0 & 32 & 90 & 32 & 4.0 & 0.781 & 8 \\
\hline $\begin{array}{l}\text { 4) Students are skilled } \\
\text { and knowledgeable in the } \\
\text { field of work. }\end{array}$ & 1 & 2 & 34 & 81 & 38 & 4.0 & 0.786 & 7 \\
\hline $\begin{array}{l}\text { 5) Students practice self- } \\
\text { safety awareness aspects } \\
\text { in carrying out their } \\
\text { duties. }\end{array}$ & 1 & 0 & 13 & 73 & 68 & 4.3 & 0.851 & 2 \\
\hline $\begin{array}{l}\text { 6) Students are trying to } \\
\text { improve their skills and } \\
\text { knowledge. }\end{array}$ & 1 & 0 & 9 & 74 & 71 & 4.4 & 0.859 & 1 \\
\hline $\begin{array}{l}\text { 7) Students can master } \\
\text { their technological skills } \\
\text { well. }\end{array}$ & 1 & 0 & 14 & 89 & 51 & 4.2 & 0.828 & 3 \\
\hline $\begin{array}{l}\text { 8) Students can practice } \\
\text { filing and document } \\
\text { management well. }\end{array}$ & 1 & 0 & 22 & 83 & 50 & 4.2 & 0.822 & 4 \\
\hline
\end{tabular}

\section{Soft Skills for Industrial Training Students}

Soft skills include communication skills, critical skills and problem-solving, teamwork skills, lifelong learning, information management, entrepreneurial skills, ethics, professionalism, and leadership skills. Table 6 shows the ranking of Soft skills for Industrial Training Students under eight (8) levels of students' soft skills domain. First, it shows that majority of the students can communicate well with coworkers. Next, the students can communicate well with employers, followed by their ability to commit to teamwork well. Finally, however, they ranked their ability to think critically in solving problems as 
the least important. It indicates that the learning style such as group presentation or working group assignment contributes to their communication skills and teamwork development.

Table 6. Ranking of soft skills for industrial training students using

Relative Important Index (RII)

\begin{tabular}{|c|c|c|c|c|c|c|c|c|}
\hline \multirow{2}{*}{$\begin{array}{l}\text { Level of soft } \text { skills for } \\
\text { Industrial } \\
\text { Students }\end{array}$} & \multicolumn{5}{|c|}{$\begin{array}{l}\text { Level of Agreement using the } \\
\text { Likert Scale }\end{array}$} & \multirow[t]{2}{*}{ Mean } & \multirow[t]{2}{*}{ RII } & \multirow[t]{2}{*}{ Rank } \\
\hline & 1 & 2 & 3 & 4 & 5 & & & \\
\hline $\begin{array}{l}\text { 1) Students can } \\
\text { communicate well with } \\
\text { employers. }\end{array}$ & 1 & 0 & 9 & 79 & 65 & 4.3 & 0.847 & 2 \\
\hline $\begin{array}{l}\text { 2) Students can } \\
\text { communicate well with } \\
\text { co-workers. }\end{array}$ & 1 & 0 & 6 & 66 & 81 & 4.5 & 0.871 & 1 \\
\hline $\begin{array}{l}\text { 3) Students can solve the } \\
\text { problem well. }\end{array}$ & 1 & 0 & 20 & 85 & 47 & 4.2 & 0.805 & 7 \\
\hline $\begin{array}{l}\text { 4) Students can think } \\
\text { critically in solving } \\
\text { problems. }\end{array}$ & 1 & 1 & 35 & 82 & 35 & 4.0 & 0.773 & 8 \\
\hline $\begin{array}{l}\text { 5) Students can commit to } \\
\text { teamwork well. }\end{array}$ & 1 & 0 & 11 & 74 & 67 & 4.3 & 0.842 & 3 \\
\hline $\begin{array}{l}\text { 6) Students can practice } \\
\text { ethics and } \\
\text { professionalism } \\
\text { throughout the training } \\
\text { period. }\end{array}$ & 1 & 0 & 13 & 83 & 57 & 4.3 & 0.832 & 5 \\
\hline $\begin{array}{l}\text { 7) Students can adapt to } \\
\text { the current situation. }\end{array}$ & 1 & 0 & 10 & 80 & 62 & 4.3 & 0.837 & 4 \\
\hline $\begin{array}{l}\text { 8) Students can fully } \\
\text { utilize the ample time. }\end{array}$ & 1 & 0 & 13 & 81 & 58 & 4.3 & 0.828 & 6 \\
\hline
\end{tabular}

\section{Correlation between 4 Major Skill Domains}

Table 7 shows the inter-correlation between 4 major skills domains: knowledge, personality, generic skills, and soft skills.

Table 7. Inter-correlation between 4 major skills domains.

\begin{tabular}{lllll}
\hline Domains & Knowledge & Personality & Generic skills & Soft skills \\
\hline Knowledge & - & $* 0.632$ & -0.409 & -0.485 \\
Personality & $* 0.632$ & - & -0.227 & -0.068 \\
Generic skills & -0.409 & -0.227 & - & $* 0.381$ \\
Soft skills & -0.485 & -0.068 & $* 0.381$ & - \\
\hline
\end{tabular}

Immense strength and positive correlation were found between "knowledge" and "personality" based on a given scenario; $r=0.632$. It means that if the student has high knowledge, it may also contribute to a high level of personality in terms of punctuality, good teamwork, and trustworthiness. Medium strength and positive correlation were found between "soft skills" and "generic skills"; $r=$ 0.381. If the student has high soft skills, it may also affect their generic skills in terms of working independently, good communication skills, and adapting to the current situation.

\section{DISCUSSION}

The result of this study has several important theoretical implications. The knowledge can influence the students' personality because the measurement of the knowledge also depends on the 
quality of the work. Assessing whether people's personality preferences are linked to employability attributes may provide useful information for Higher Institutional Learning to develop employability attributes and skills. Furthermore, the study could provide new insights and perspectives informing career development support practices for young adults transitioning into the workforce. Another soft skill that merited sub-categorization is teamwork, which allows workers to both leads and obey. They should also be able to work individually to accomplish their tasks to achieve a common achievement. The input from this study on students' awareness and soft skills results gained from industrial training programs will provide valuable information to the university and organizations, which can be shared with program coordinators and administrators. Employer insights should be considered critical components of a holistic assessment of students' results. As a result, the input received can be used to enhance industrial training or internship programs and upgrade the outcomes of the academic programs to provide a high quality of graduates for a potential market. However, certain added value skills should be considered when dealing with specialized internship programs such as pharmacy, engineering, and pure science.

\section{CONCLUSION}

Based on the findings, industrial training students of the UiTM Pahang Civil Engineering Diploma Program comply with the four variables studied. It means the students have met all the criteria that the employer required. The findings indicate that employers are satisfied with the industrial training students of the UiTM Pahang Civil Engineering Diploma Program, either from knowledge empowering, personality, generic skills, or soft skills. Besides, it also shows a good correlation between knowledge and personality among industrial training students. Based on the four highlighted factors focused on this study, it is suggested that industrial training course outcomes need to be revised periodically to fulfill an employer's requirements and produce high-quality graduates to serve in the rapid development country for a better future. In addition, a future study could be planned to identify some possible differences in soft skills among students from various fields of study, especially those in engineering studies. Factors that lead to such inequalities must be recognized, and the findings will help local higher education institutions create improved curricula in their attempts to produce better graduates.

\section{Funding and Conflicts of Interest}

The author declares that there is no funding and conflicts of interest for this research.

\section{REFERENCES}

Ariff, M., Lim, B., \& Janice, L. H. N. (2017). Soft Skills Attributes and Graduate Employability: A Case in Universiti Malaysia Sabah Muhammad Ariff Nazron. Malaysian Journal of Business and Economics, $4(2), 65-76$.

Azmi, A. N., Kamin, Y., Noordin, M. K., \& Ahmad, A. N. (2018). Towards industrial revolution 4.0: Employers' expectations on fresh engineering graduates. International Journal of Engineering and Technology(UAE), 7(4), 267-272. https://doi.org/10.14419/ijet.v7i4.28.22593

Carneiro da Cunha Custódio, L., \& Gomes da Silva, J. (2020). Profile of Supervised Internship Reports of the FT/UFAM Industrial Engineering Course. International Journal for Innovation Education and Research, 8(3), 175-184. https://doi.org/10.31686/ijier.vol8.iss3.2221

Chiu, L. K., Mahat, N. I., Rashid, B., Razak, N. A., \& Omar, H. (2016). Assessing Students' Knowledge and Soft Skills Competency in the Industrial Training Programme: The Employers' Perspective. Review of European Studies, 8(1), 123. https://doi.org/10.5539/res.v8n1p123

Devi, F. A., Rofiq, Z., \& Purnomo, E. (2019). Analysis of an industrial internship in the department of mechanical engineering with servqual, kano, and quality function deployment. IOP Conference Series: Materials Science and Engineering, 535(1). https://doi.org/10.1088/1757$\underline{899 X / 535 / 1 / 012006}$ 
Fairuzza, Mohamad Nazuir, \& Wahid. (2011). Employers' Perception On Soft Skills Of Graduates : A Study Of Intel Elite Soft Skill Training. International Conference on Teaching \& Learning in Higher Education, Ictlhe.

Gibert, A., Tozer, W. C., \& Westoby, M. (2017). Teamwork, Soft Skills, and Research Training. Trends in Ecology and Evolution, 32(2), 81-84. https://doi.org/10.1016/j.tree.2016.11.004

Goller, M., Harteis, C., Gijbels, D., \& Donche, V. (2020). Engineering students' learning during internships: Exploring the explanatory power of the job demands-control-support model. Journal of Engineering Education, 109(2), 307-324. https://doi.org/10.1002/jee.20308

Hashamuddin Yaakob, Radzi, N. F., Ahmad Sudan, R., Yaakob, H., Farazila, N., \& Ahmad, R. (2018). Employers' Perception on Malaysian Polytechnic Graduates Employability Skills. First International Multidisciplinary Academic Conference 2018, October, 1-8.

Ilhaamie, A. G. A., Rosmawani, C. H., \& Yusmini, M. Y. (2018). The employability skills of Malaysian university students. International Journal of Modern Trends in Social Sciences, 1(3), 1-14.

Mai, R. C. (2012). Developing soft skills in Malaysian Polytechnic students: Perspectives of employers and students. Asian Journal of Management Sciences and Education, 1(2), 44-51.

Matturro, G., Raschetti, F., \& Fontán, C. (2019). A systematic mapping study on soft skills in software engineering. Journal of Universal Computer Science, 25(1), 16-41.

Mihail, D. M. (2006). Internships at Greek universities: An exploratory study. Journal of Workplace Learning, 18(1), 28-41. https://doi.org/10.1108/13665620610641292

Ng, K. H., \& Ahmad, R. (2018). Personality traits, social support, and training transfer: The mediating mechanism of motivation to improve work through learning. Personnel Review, 47(1), 39-59. https://doi.org/10.1108/PR-08-2016-0210

Pereira, O., \& Raposo, M. J. (2019). Soft Skills in Knowledge-Based Economics non-traditional. Marketing and Management of Innovations, 6718(1), 182-195.

Rothman, M. (2007). Lessons Learned: Advice to Employers From Interns. Journal of Education for Business, 82(3), 140-144. https://doi.org/10.3200/joeb.82.3.140-144

Shakir, R. (2009). Soft skills at the Malaysian institutes of higher learning. Asia Pacific Education Review, 10(3), 309-315. https://doi.org/10.1007/s12564-009-9038-8

Shazaitul Azreen Binti Rodzalan. (2016). The influence of individual and organisational factors on university students' generic skills. Utm.

Warinda, T. (2020). Accounting Students' Evaluation of Internship. International Journal of Asian Social Science, 3(3), 783-799.

Zhukova, O. A. (2020). Developing communication skills of students of humanitarian and natural specialties as a soft skill in the process of training. November 2020. https://doi.org/10.30525/9789934-588-80-8-2.6 